\title{
Effect of Vertical Drains on Strength and Deformation Characteristics of Lithomargic Clay
}

\author{
Deepak Nayak, Purushotham G. Sarvade, H. N. Udaya Shankara
}

\begin{abstract}
During olden days, construction used to be carried out only on the sites having good strength. But now-a-days availability of sites with favourable properties are limited. So, there is a need to modify the properties of subsoil using different types of Ground Improvement Techniques. Depending upon the nature of soil, a suitable economical technique needs to be adopted. Soft soils have weaker strength and they are highly compressible and take a lot of time for settlement. So, these are typically problematic for construction. There is a need to improve the condition by accelerating the rate of consolidation. To achieve higher rate of consolidation, it is important to develop shorter paths for movement of the water. A vertical drainage system can be provided to accelerate the rate of consolidation and help to minimise excess pore pressure in the sub-soil. As a result of this, a stable situation is reached more quickly. Thus to enhance the strength of the soil and to accelerate the consolidation rate, vertical drains of different diameters and with varied spacing are employed. The improvement in properties of soft consolidating lithomargic clay is experimentally tested with vertical sand drains in developed prototype. The vertical sand drains installed with 1.905 (0.75 inch) diameter and $6 \mathrm{~cm}$ spacing is more effective in increasing Ultimate Bearing Capacity (UBC) of soil and also the rate of settlement of $35.26 \%$ is significant up to $60 \mathrm{~kg}$ of preloads. Thus problematic lithomargic clay can be improved in its strength and settlement characteristics.
\end{abstract}

Keywords: Lithomargic clay, Ultimate Bearing Capacity, Rate of consolidation, Vertical drains.

\section{INTRODUCTION}

With the rapid modernization of towns and industries, there is a beginning to a new era which needs all kinds of resources. One such major resource is land availability. As favourable land is not available in abundance, there is a need to improve the available unfavourable land, as these soils may not have adequate geotechnical or engineering properties. The soils and its properties varies from place to place and each one has its own characteristics. These can sometimes result in poor drainage system, decreased bearing capacity etc. These issues may also be due to reasons such as

Revised Manuscript Received on December 30, 2019.

* Correspondence Author

Deepak Nayak*, Assistant Professor, Department of Civil Engineering, Manipal Institute of Technology, MAHE, Manipal, India,

E-mail: dnnayak@gmail.com.

Purushotham G. Sarvade, Professor, Department of Civil Engineering, Manipal Institute of Technology, MAHE, Manipal, India,

E-mail: pgsarvade@gmail.com.

H. N. Udaya Shankara, Professor, Department of Civil Engineering, Manipal Institute of Technology, MAHE, Manipal, India,

E-mail: udaya.shankar@manipal.edu.

(c) The Authors. Published by Blue Eyes Intelligence Engineering and Sciences Publication (BEIESP). This is an open access article under the CC BY-NC-ND license (http://creativecommons.org/licenses/by-nc-nd/4.0/) filled sites, low-lying waterlogged areas, waste lands, lands filled with high deposits of soft saturated marine clay or site location in seismic areas. Soil consolidates only in vertical direction due to preloads. In addition to pre-loading, we can increase the consolidation speed by using vertical drains. This results in reduction of lesser pre-load. It increases the consolidation rates significantly by facilitating combination of radial and vertical consolidation. Ground Improvement technique consists of Hydraulic, Mechanical, Physical, Chemical, biological modifications or combination of such methods and modification by inclusions [1]. In the case of highly consolidating soils, there are many techniques which are involved for the improvement of the same. Soft soils have weaker strength and they are highly compressible and take a lot of time for settlement. So, these are typically problematic for construction. It is difficult to rely on engineering properties of this type of soil. There is a need to improve the condition by accelerating the rate of consolidation and by improving the soil we can also reduce the depth of the foundations which bear heavier loads making it more economical.

The theory of consolidation according to Terzaghi, states that for a given soil mass the time required to reach a particular degree of primary consolidation is directly proportional to the square of the longest drainage path. If the travel distance of the water in a soil mass is decreased, then consolidation occurs more quickly. This can be attained by installing drains [2].

As the clay is less permeable, the consolidation settlement of soft clay requires a longer time for completion. To reduce the duration of consolidation settlement, vertical drains are placed either with an embankment or by applying vacuum pressure as preloads.

The vertical drains with a specific pattern enable both a radial and a vertical water flow in the soil. The water from the drains is transported to a drainage cloak on the surface or deeper into highly permeable layers in the soil. The combination of vertical and radial water flow reduces the time needed for consolidation settlement than that of vertical flow depending upon the spacing of the drain. The drains reduce the excess pore pressure during consolidation by squeezing it out of a soil.

The lithomargic clay, generally found below the lateritic soil. This soil constitutes major portion of silt deposits. This lithomargic clay is dispersive in nature and is liable to erosion, which is largely found in the western coast of South India. Since the soil has high silt content and high sensitivity towards the water, it invites many problems such as uneven or excessive settlement, slope failure, embankment failures and foundation failures. 
The lithomargic clay in its saturated conditions show a significant reduction in strength. The study on lithomargic clay witnessed the improvement in the geotechnical properties after mixed with cement and crusher dust [3].

The coefficient of permeability rises with percentage increase in sand content and decreases with with percentage of coir increase in lithomargic soil as studied by [4]. They also found the CBR value in both soaked and unsoaked condition increases with the increase in sand and coir. The Unconfined compressive strength (UCS) increases up to a certain limit with the increase in sand percentage whereas UCS increases continuously with increase in percentage of coir. Experiments conducted by [5] tested the suitability of lithomargic clay combined with $5 \%$ marine clay to act as landfill liner material. They stated that low permeability, strength, potential to shrink make blended lithomargic clay an ecofriendly potential landfill liner material. As per the study of [6], the randomly distributed tyre chips induce friction to the lithomargic clay, indicated by the increase in the internal angle of friction $(\Phi)$. The value of California Bearing Ratio ( CBR ) of lithomargic clay can be effectively increased when modified with optimum dosage of cement and randomly distributed tyre rubber pieces. Addition of 35\% fly ash to the lithomargic clay was found to be optimum and maximum unconfined strength of $321.14 \mathrm{kPa}$ was achieved after 90 days of curing as investigated by [7]. They also stated that addition of sodium salts such as sodium chloride $(\mathrm{NaCl})$ and sodium hydroxide $(\mathrm{NaOH})$ at $1 \%$ on the clay-fly ash further increases the UCS values. In the study conducted by [8], polypropylene strips were added at concentrations of $1 \%$, $2 \%, 3 \%$ and $4 \%$ and it was observed that the strength of the soil was improved at each percentage of addition. However, a maximum compressive strength was observed at optimum proportion of $3 \%$.

Coastal part of Karnataka is an area which is highly stressed due to developmental activities. Lithomargic clay is a type of soil which is found below laterite along coastal Karnataka, which requires an extensive study to make it suitable to withstand any engineering structure like buildings, pavements, railways, dams etc. The cost of construction can be minimised by selecting locally available materials including locally available soils for the construction.

\section{METHODOLOGY}

The research aims at exploring the behaviour of vertical drains in improving the soft consolidating soil. A positivism paradigm is selected as it includes quantitative evaluation of variables through experimentation. Here a deductive mode will be considered and empirical strategy is used. Experimental method will be used as it is possible to identify the effect of independent variable (diameter of vertical sand drains and spacing of vertical drains) on the dependent variable (Ultimate bearing capacity of soil and rate of consolidation). Simulation technique is considered for the performance evaluation of vertical sand drains in improving the soil properties.

\section{A. Identification of soft consolidating soil}

The soil selected is a soft consolidating soil collected from Kolalgiri, Udupi which is highly compressible in nature. The purposive sampling method is adopted since the soil required

was soft consolidating soil. A grid is formed to take sample from various parts and then mixed thoroughly to get homogeneous sample for testing.

\section{B. Conducting basic geotechnical tests}

The soil thus collected is evaluated by conducting all the basic geotechnical tests like Specific gravity, gradation analysis, Hydrometer analysis, Consistency limit test, Standard proctor compaction test as per IS standard procedure.

\section{Design of Laboratory model}

After evaluating the soil samples and identification of soft consolidating soil, a laboratory prototype is developed to simulate the field conditions as shown in the figure Fig. 1. The soil is filled in the rectangular tank of dimension $0.5 \mathrm{~m}$ $* 0.5 \mathrm{~m} * 1 \mathrm{~m}$ and then subjected to the static load with the help of rectangular plate on the top surface of the soil. A plate of size $0.1 \mathrm{~m}$ x $0.1 \mathrm{~m}$ will be placed at the center to load the soil and is maintained till the end of consolidation process. The load versus deformations are studied with the various cases. The tests are conducted for soils with and without vertical drains.

The testing is carried out with a triangular pattern of vertical drains. The test is conducted to investigate the influence of various diameter of vertical sand drains (independent variable) for $1.27 \mathrm{~cm}$ (0.5 inch), $1.905 \mathrm{~cm}$ (0.75 inch) and $2.54 \mathrm{~cm}$ (1.0 inch) with different spacings (independent variable) of $6 \mathrm{~cm}, 8 \mathrm{~cm}$ and $10 \mathrm{~cm}$ on the ultimate bearing capacity (dependent variable) of the soil and rate of consolidation (dependent variable). The test is performed for various increment in load from $10 \mathrm{~kg}(0.098 \mathrm{kN})$ to $100 \mathrm{~kg}$ $(0.981 \mathrm{kN})$ at an interval of $10 \mathrm{~kg}(0.0981 \mathrm{kN})$

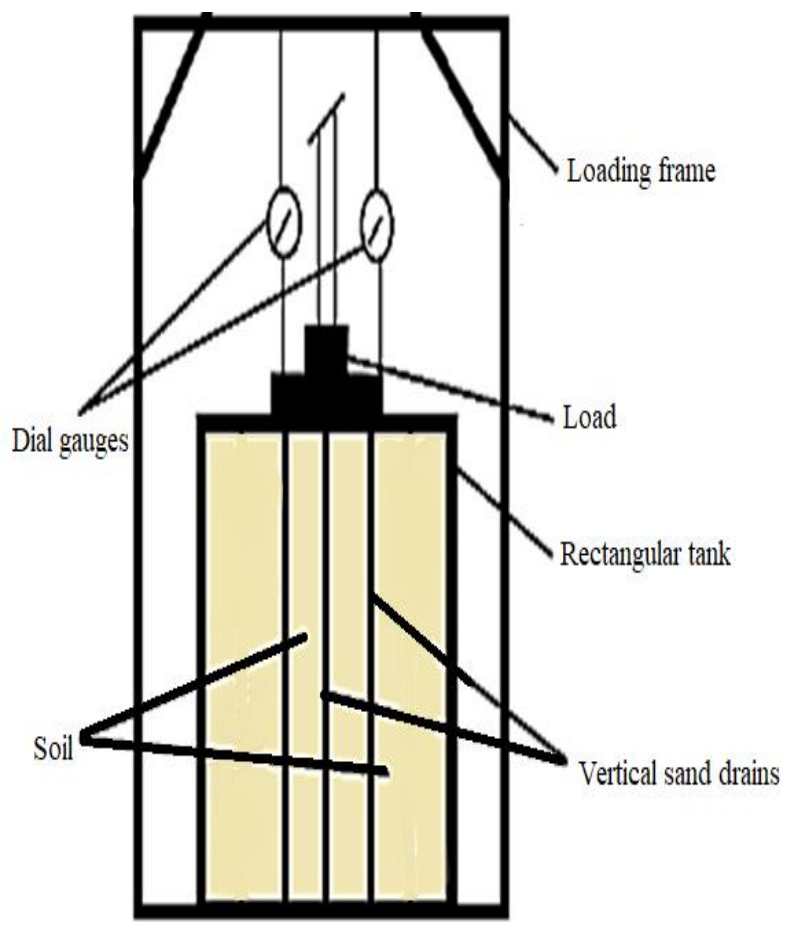

Fig. 1. Elevation of prototype 


\section{RESULTS AND DISCUSSIONS}

\section{A. Basic geotechnical properties of the soil}

The results of geotechnical tests are shown in the Table 1.

Table- I: Basic geotechnical properties

\begin{tabular}{|c|c|c|}
\hline \multicolumn{2}{|c|}{ Physical Property } & Value \\
\hline Specific Gravity & & 2.52 \\
\hline \multirow{2}{*}{$\begin{array}{c}\text { Grain size } \\
\text { Analysis }\end{array}$} & Gravel size (\%) & 3 \\
\cline { 2 - 3 } & Silt \& Clay size (\%) & 69 \\
\hline \multirow{3}{*}{$\begin{array}{c}\text { Atterberg } \\
\text { Limits }\end{array}$} & Liquid Limit (\%) & 48.17 \\
\cline { 2 - 3 } & Plastic Limit (\%) & 31.65 \\
\cline { 2 - 3 } & Shrinkage Limit (\%) & 28.36 \\
\cline { 2 - 3 } & Plasticity Index (\%) & 16.52 \\
\hline \multicolumn{2}{|c|}{ Maximum Dry Density( kN/m³) } & 15.94 \\
\hline \multicolumn{2}{|c|}{ Optimum Moisture Content (\%) } & 19 \\
\hline
\end{tabular}

From the geotechnical test results, soil comes under the classification of medium plastic silt. It can be concluded that the soil is rich in silt and clay which is soft consolidating soil.

\section{B. Consolidation of soil without vertical drains}

The consolidation of basic soil is carried out in the laboratory without vertical drains and the settlements are recorded for every load increment. The results are plotted as shown in Fig. 2.

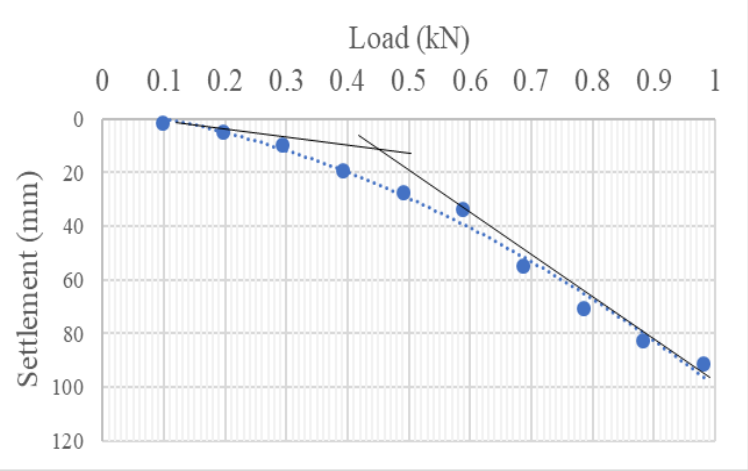

Fig. 2. Settlement vs Load - Without Vertical Drains

\section{Consolidation of soil with vertical drain}

The bearing capacity and rate of consolidation are calculated for various diameters and spacings of vertical drains as follows:

Case 1: Vertical sand drain of $1.27 \mathrm{~cm}$ (0.5 inch) diameter with $6 \mathrm{~cm}$ spacing

From Fig. 3, the ultimate bearing capacity of soil for $1.27 \mathrm{~cm}$ diameter and $6 \mathrm{~cm}$ spacing is found out to be 51 $\mathrm{kN} / \mathrm{m}^{2}$. For the pre-loads of $0.098 \mathrm{kN}$ to $0.59 \mathrm{kN}$, it showed a significant effect of vertical drains than that of soils without vertical drains.

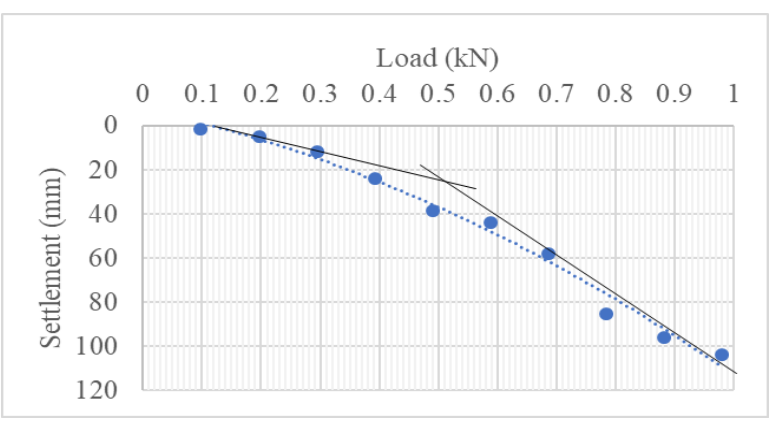

Fig. 3.Settlement vs Load $-1.27 \mathrm{~cm}$ diameter and $6 \mathrm{~cm}$ spacing

Case 2: Vertical sand drain of $1.905 \mathrm{~cm}$ (0.75 inch) diameter with $6 \mathrm{~cm}$ spacing

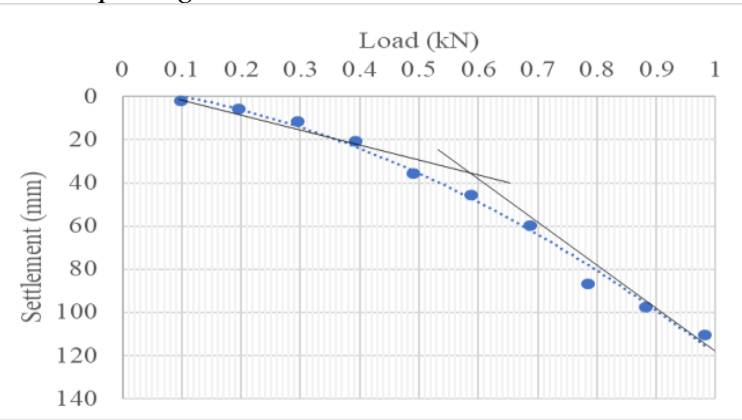

Fig. 4. Settlement vs Load $-1.27 \mathrm{~cm}$ diameter and $6 \mathrm{~cm}$ spacing

From Fig. 4, the ultimate bearing capacity of soil for 1.905 cm diameter with $6 \mathrm{~cm}$ spacing is found out to be $59 \mathrm{kN} / \mathrm{m}^{2}$. For the pre-loads of $0.098 \mathrm{kN}$ to $0.59 \mathrm{kN}$, it showed a significant effect of vertical drains than that of soils without vertical drains. A maximum ultimate bearing strength is observed at this combination and also the rate of settlement of $35.28 \%$ is significant up to $0.59 \mathrm{kN}$ and final settlement is observed to be higher than soil without vertical drain.

Case 3: Vertical sand drain of $2.54 \mathrm{~cm}$ (1 inch) diameter with $6 \mathrm{~cm}$ spacing

From Fig 5, the ultimate bearing capacity of soil for $2.54 \mathrm{~cm}$ diameter with $6 \mathrm{~cm}$ spacing is found out to be $55 \mathrm{kN} / \mathrm{m} 2$. In this pattern of vertical drain, there is no significant increase in consolidation but the ultimate bearing capacity of the soil shows relatively higher value may be because of reinforcing effect caused by vertical drain.

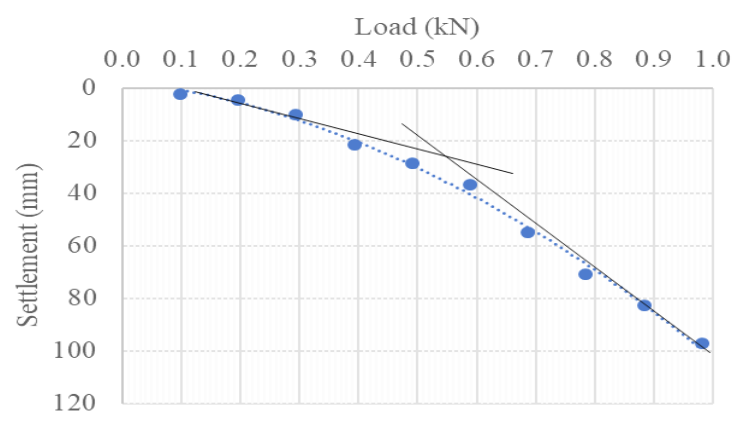

Fig. 5.Settlement vs Load for $2.54 \mathrm{~cm}$ diameter with $6 \mathrm{~cm}$ spacing 


\section{Effect of Vertical Drains on Strength and Deformation Characteristics of Lithomargic Clay}

Case 4: Vertical sand drain of $1.27 \mathrm{~cm}$ (0.5 inch) diameter with $8 \mathrm{~cm}$ spacing

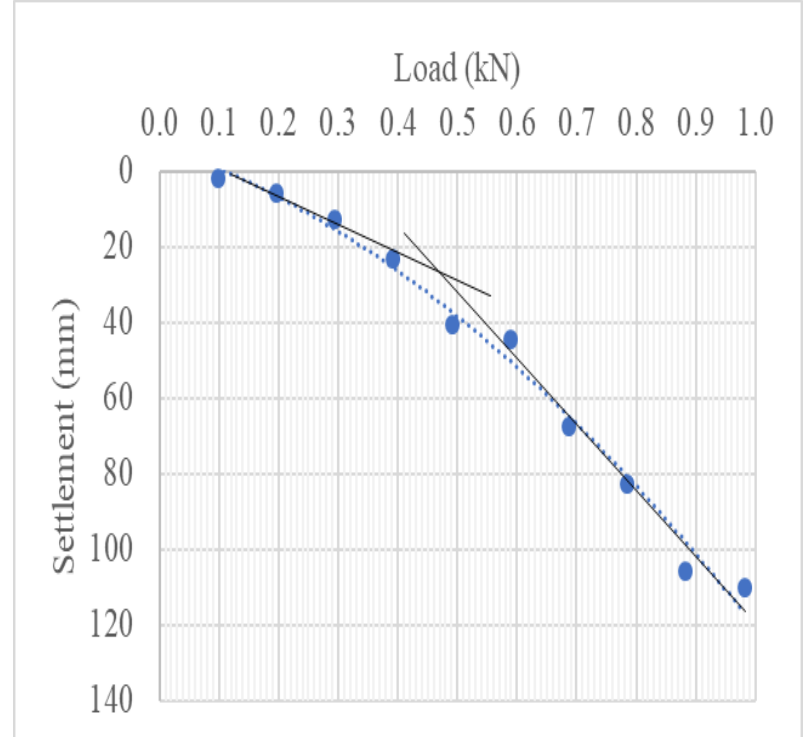

Fig. 6. Settlement vs Load for $1.27 \mathrm{~cm}$ diameter with $8 \mathrm{~cm}$ spacing

From Fig. 6, the ultimate bearing capacity of soil for $1.27 \mathrm{~cm}$ diameter and $8 \mathrm{~cm}$ spacing is found out to be $47 \mathrm{kN} / \mathrm{m}^{2}$. The rate of consolidation is significant up to a preloading of 0.59 $\mathrm{kN} \mathrm{kg}$ ranges from $25 \%$ to $45 \%$ compared to soil without vertical drain. The final settlement of the soil of $110 \mathrm{~mm}$ is higher than the soil without vertical drain.

Case 5: Vertical sand drain of $1.905 \mathrm{~cm}$ (0.75 inch) diameter with $8 \mathrm{~cm}$ spacing

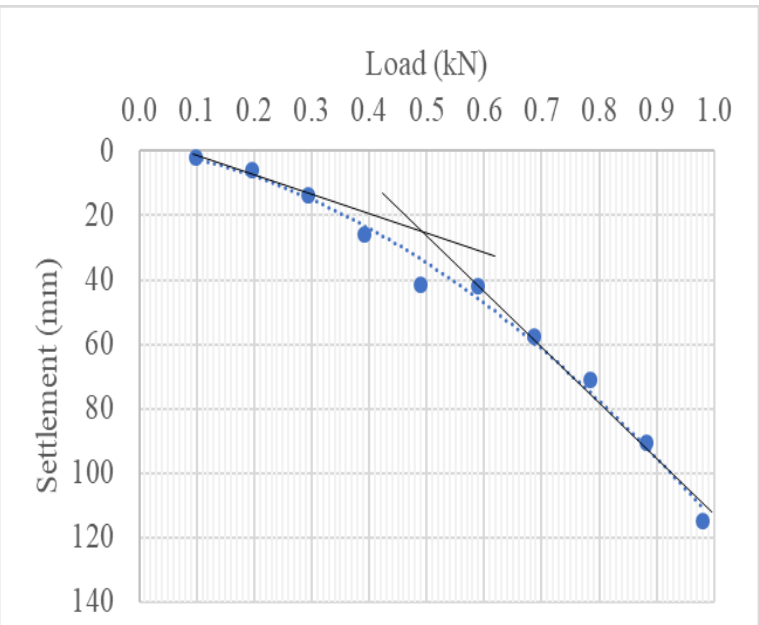

Fig. 7. Settlement vs Load for $1.905 \mathrm{~cm}$ diameter with 8 cm spacing

From Fig. 7, the ultimate bearing capacity of soil for 1.905 $\mathrm{cm}$ diameter and $8 \mathrm{~cm}$ spacing is found out to be $49 \mathrm{kN} / \mathrm{m}^{2}$.

The rate of consolidation is significant up to a preloading of $0.59 \mathrm{kN}$ ranges from $14 \%$ to $51 \%$ compared to soil without vertical drain. The final settlement of the soil of $115.03 \mathrm{~mm}$ is higher than the soil without vertical drain.

Case 6: Vertical sand drain of $2.54 \mathrm{~cm}$ (1 inch) diameter with $8 \mathrm{~cm}$ spacing

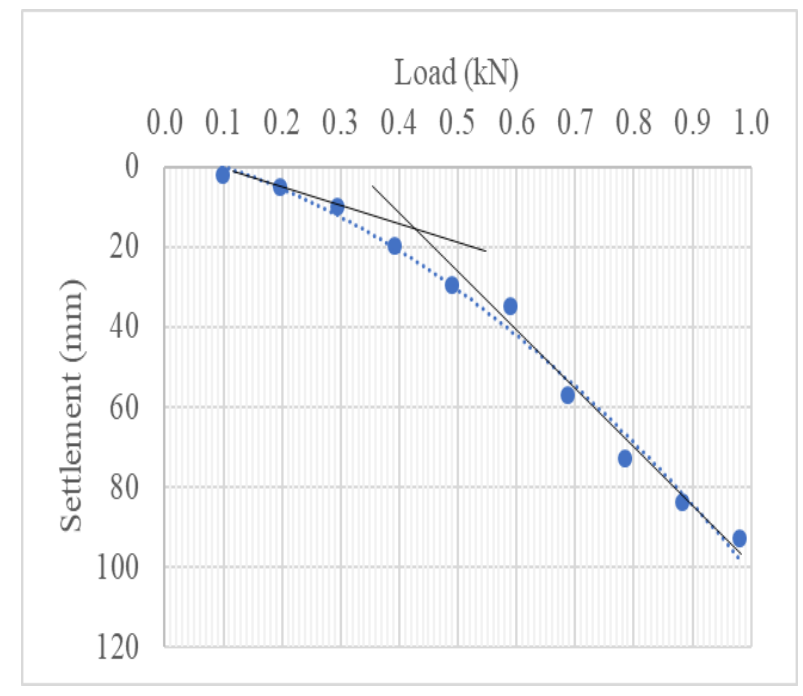

Fig. 8. Settlement vs Load for $2.54 \mathrm{~cm}$ diameter with $8 \mathrm{~cm}$ spacing

From Fig. 8, the ultimate bearing capacity of soil for 2.54 $\mathrm{cm}$ diameter and $8 \mathrm{~cm}$ spacing is found out to be $43 \mathrm{kN} / \mathrm{m}^{2}$. The rate of consolidation is not significant for any of the preloading and moderately higher than soil without vertical drain.

Case 7: Vertical sand drain of $1.27 \mathrm{~cm}$ (0.5 inch) diameter with $10 \mathrm{~cm}$ spacing

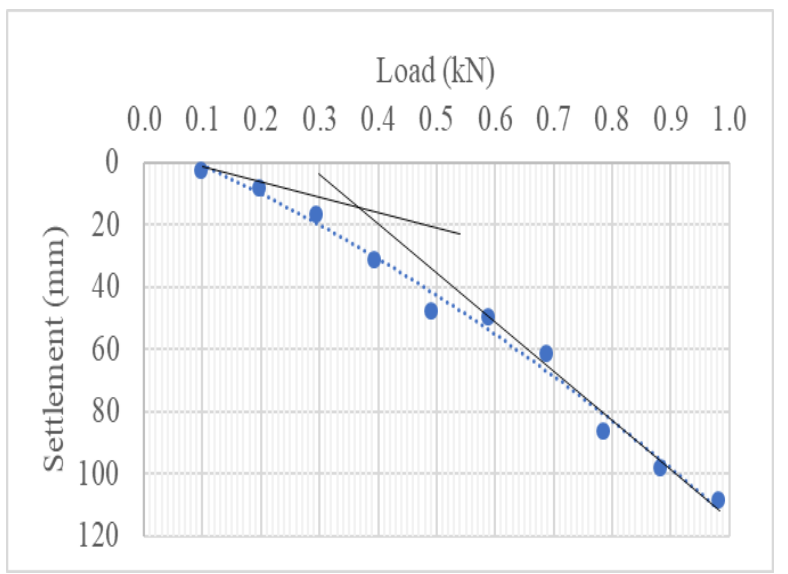

Fig. 9. Settlement vs Load for $1.27 \mathrm{~cm}$ diameter with 10 cm spacing

From Fig. 9, the ultimate bearing capacity of soil for 1.27 $\mathrm{cm}$ diameter and $10 \mathrm{~cm}$ spacing is found out to be $37 \mathrm{kN} / \mathrm{m}^{2}$. The rate of settlement is observed to be significantly high up to preloads of $0.49 \mathrm{kN}$.

Case 8: Vertical sand drain of $1.905 \mathrm{~cm}$ (0.75 inch) diameter with $10 \mathrm{~cm}$ spacing

From Fig. 10, the ultimate bearing capacity of soil for 1.905 $\mathrm{cm}$ diameter and $10 \mathrm{~cm}$ spacing is found out to be 39 $\mathrm{kN} / \mathrm{m}^{2}$. The rate of consolidation is significant up to preloads of $0.49 \mathrm{kN}$ and moderate at other preloads.

Published By: 


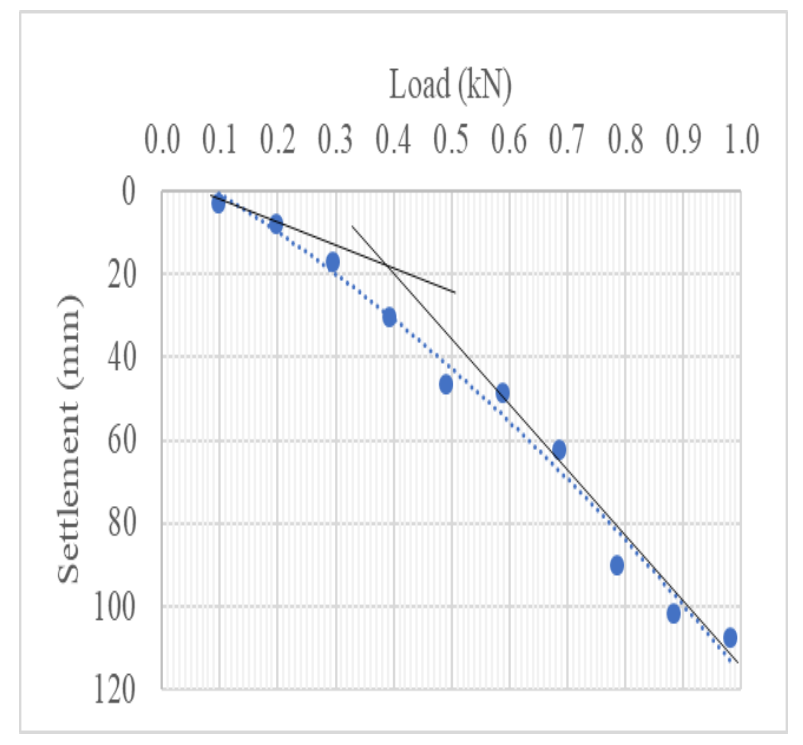

Fig. 10. Settlement vs Load for $1.905 \mathrm{~cm}$ diameter with $10 \mathrm{~cm}$ spacing

Case 9: Vertical sand drain of $2.54 \mathrm{~cm}$ (1 inch) diameter with $10 \mathrm{~cm}$ spacing

From Fig. 11, the ultimate bearing capacity of soil for 2.54 $\mathrm{cm}$ diameter and $10 \mathrm{~cm}$ spacing is found out to be $47 \mathrm{kN} / \mathrm{m} 2$. The rate of consolidation and final settlement is less than the soil without vertical drains but ultimate bearing capacity is relatively higher may be due to the sand column effect caused by installed vertical sand drains.

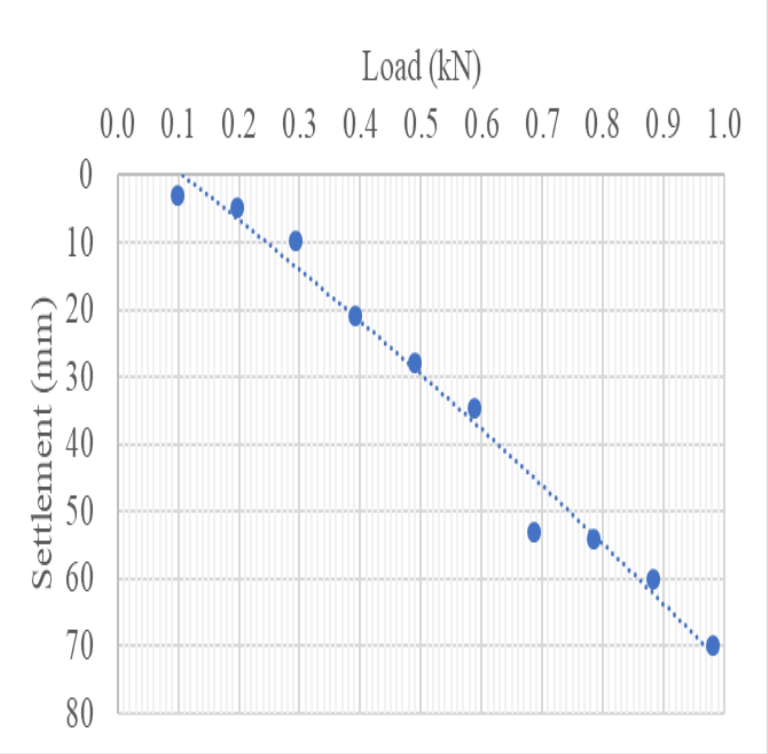

Fig. 11. Settlement vs Load for $2.54 \mathrm{~cm}$ diameter with $10 \mathrm{~cm}$ spacing

The values of Ultimate bearing capacity (UBC) of various combinations are tabulated in the below table (Table II).

\section{Rate of Consolidation}

The rate of consolidation with respect to the settlement corresponding to each preloads are shown in the Table III and Fig. 12.
Table- II: UBC values for different diameters and spacings

\begin{tabular}{|c|c|c|}
\hline \multicolumn{2}{|c|}{ Experimental setup } & $\begin{array}{c}\text { UBC } \\
\left(\mathbf{k N} / \mathrm{m}^{2}\right)\end{array}$ \\
\hline \multicolumn{2}{|c|}{$\begin{array}{c}\text { Soil Without vertical } \\
\text { drains }\end{array}$} & 45 \\
\hline \multirow{9}{*}{$\begin{array}{c}\text { Soil } \\
\text { With } \\
\text { vertical } \\
\text { drains }\end{array}$} & Case 1 & 51 \\
\hline & Case 2 & 59 \\
\hline & Case 3 & 55 \\
\hline & Case 4 & 47 \\
\hline & Case 5 & 49 \\
\hline & Case 6 & 43 \\
\hline & Case 7 & 37 \\
\hline & Case 8 & 39 \\
\hline & Case 9 & 47 \\
\hline
\end{tabular}

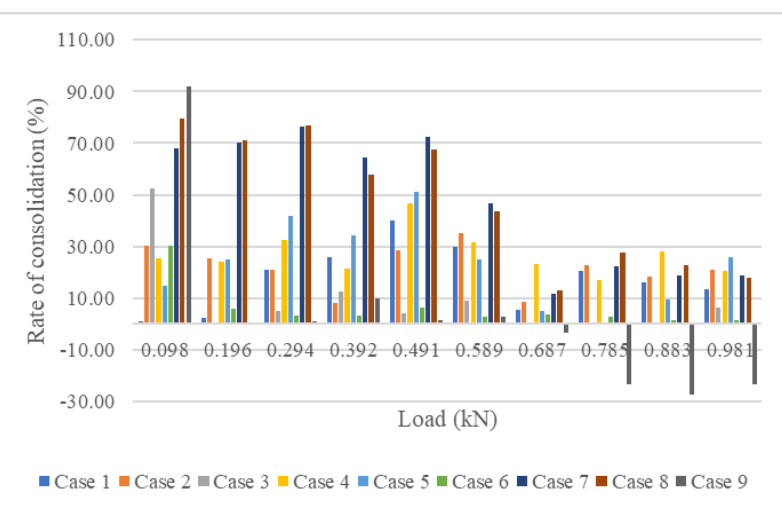

Fig. 12. Variation of rate of consolidation for different preloads.

\section{CONCLUSION}

The following conclusions can be derived based on the experimental investigation,

- The properties of soft consolidating lithomargic clay can be improved using vertical sand drains.

- The vertical sand drains installed with 1.905 (0.75 inch) diameter and $6 \mathrm{~cm}$ spacing is more effective in increasing ultimate bearing capacity ( UBC ) of the soil and also the rate of settlement of $35.26 \%$ is significant up to $0.59 \mathrm{kN}$ of preloads.

- Considering the various combinations of diameter and spacings, in most of the cases, the consolidation rate is high up to $0.59 \mathrm{kN}$ of preloads and then decreases indicating the effective performance of vertical drains in accelerating the consolidation process.

- The rate of consolidation and final settlement may be less than the soil without vertical drains but ultimate bearing capacity is relatively higher may be due to the reinforcing column effect caused by installed vertical sand drains as in case

9. 
Table- III: The rate of consolidation with various experimental setup

\begin{tabular}{|l|l|l|l|l|l|l|l|l|l|}
\hline $\begin{array}{l}\text { Load } \\
(\mathrm{kN})\end{array}$ & Case 1 & Case 2 & Case 3 & Case 4 & Case 5 & Case 6 & Case 7 & Case 8 & Case 9 \\
\hline 0.098 & 0.951 & 30.16 & 52.44 & 25.48 & 14.83 & 30.16 & 68.12 & 79.34 & 92.08 \\
\hline 0.196 & 2.245 & 25.27 & 0.47 & 23.98 & 24.95 & 5.94 & 70.07 & 71.23 & 0.47 \\
\hline 0.294 & 20.905 & 20.85 & 5.23 & 32.49 & 41.76 & 3.10 & 76.27 & 76.67 & 0.93 \\
\hline 0.392 & 25.852 & 8.06 & 12.73 & 21.44 & 34.19 & 3.39 & 64.40 & 58.03 & 9.76 \\
\hline 0.491 & 39.903 & 28.54 & 4.03 & 46.73 & 51.17 & 6.49 & 72.55 & 67.75 & 1.49 \\
\hline 0.589 & 29.774 & 35.28 & 9.05 & 31.77 & 25.05 & 2.96 & 46.93 & 43.64 & 2.69 \\
\hline 0.687 & 5.452 & 8.54 & 0.47 & 23.06 & 4.87 & 3.64 & 11.79 & 13.22 & -3.42 \\
\hline 0.785 & 20.448 & 22.64 & 0.28 & 17.00 & 0.72 & 2.98 & 22.20 & 27.58 & -23.48 \\
\hline 0.883 & 16.056 & 18.17 & 0.43 & 27.90 & 9.70 & 1.35 & 18.86 & 22.93 & -27.30 \\
\hline 0.981 & 13.380 & 21.02 & 6.19 & 20.42 & 25.93 & 1.69 & 18.85 & 17.75 & -23.37 \\
\hline
\end{tabular}

\section{REFERENCES}

1. Hausmann M. R. (1990). Engineering principles of ground modification, New Delhi: McGraw-Hill.

2. Ghulhati S. K. \& Datta M. (2008). Geotechnical Engineering, New Delhi: McGraw- Hill Publishing Company Ltd.

3. Nayak S., \& Sarvade P. G. (2011). "Effect of cement and quarry dust on shear strength and hydraulic characteristics of lithomargic clay". Geotechnical and Geological Engineering, 30(2), 419-430.

4. Shankar A. U., Chandrasekhar A., \& Bhat H. (2012). "Experimental investigations on lithomargic clay stabilized with sand and coir". Indian Highways, 40(2).

5. Allamaprabhu K., Sunil B M., Nayak S, Fernandes S \& Zafar M (2012). "Geotechnical characteristics of lithomargic clay blended with marine clay as landfill liner material”, International Journal of Earth Sciences and Engineering. 5(6), 1804-1808.

6. Marathe S., Rao B S., \& Kumar A. (2015). "Stabilization of lithomargic soil using cement and randomly distributed waste shredded rubber tyre chips". International Journal of Engineering Trends and Technology (IJETT), 23(6), 284-288.

7. H. N. Ramesh, H. S. Nanda, \& H. M. Phalachandra (2016). "Effect of Fly ash on the Strength Characteristics of Lithomargic Soil Treated with Lime and Sodium Salts", International Journal of Innovative Research in Science, Engineering \& Technology, 5(12).

8. Rao P., Varghese R., Mayya, S., Abdullah S., \& Kumar S. (2018) "Stabilization of Lithomargic Soil Using Polypropylene Strips". International Research Journal of Engineering and Technology, 5(7), 180-182.

\section{AUTHORS PROFILE}

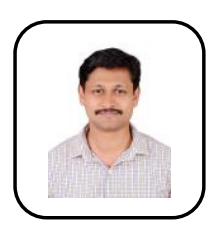

Deepak Nayak, Assistant Professor (Sr. Scale), Dept. of Civil Engineering, Completed his MTech. in Civil Engineering and doing his Research in the domain of Soil stabilization and Consolidation. Published papers in various Scopus indexed journals, National and International conferences and other Journals.

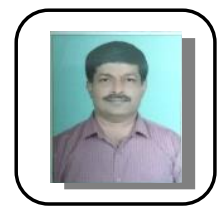

Dr. Purushotham G Sarvade, Professor, Dept. of Civil Engineering, MIT, Manipal, completed his PhD from NITK, Surathkal. Research in the domain of Soil stabilization and Consolidation. Published papers in various Scopus indexed journals, National and International conferences and other Journals.

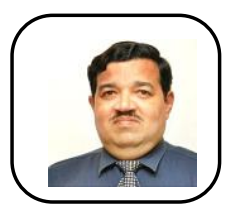

Dr. H N Udaya Shankara, Professor, Dept. of Civil Engineering, MIT, Manipal, Qualification MSc. (Geology), Ph.D. Area of Interest Geology applied to civil engineering, ground water studies, Remote sensing and GIS 